\title{
Emergence of deadly severe acute respiratory syndrome coronavirus-2 during 2019-2020
}

\author{
Arshi Islam ${ }^{1}$ - Anwar Ahmed ${ }^{2,3} \cdot$ Irshad H. Naqvi $^{4} \cdot$ Shama Parveen $^{1}$
}

Received: 22 February 2020/ Accepted: 13 March 2020/Published online: 8 April 2020

(C) Indian Virological Society 2020

\begin{abstract}
Wuhan, the city in Hubei province in China is in the focus of global community due to the outbreak of coronavirus disease 2019 (COVID-19) caused by severe acute respiratory syndrome coronavirus-2 (SARS-CoV-2), formerly known as 2019-nCoV. The virus emerged in humans from Wuhan seafood market probably via zoonotic transmission. Within a few days the virus spread its tentacles rapidly to neighboring cities in China and to different geographical regions through travelers and to some extent by human to human transmission leading to significant disease burden globally. More than 2,00,000 people (including more than 8000 deaths) have been infected with this respiratory illness across 167 countries and territories worldwide leading to a pandemic. The present review provides an outline about emergence and spread of SARSCoV-2 from Wuhan, China in 2019-2020. We have also provided information about the classification, genome, proteins, clinical presentation of COVID-19, type of clinical specimens to be collected and diagnostic methods adopted to identify the respiratory illness. In addition we have also provided information about transmission dynamics, prevention measures and treatment options that
\end{abstract}

Shama Parveen

sparveen2@jmi.ac.in; shamp25@yahoo.com

1 Centre for Interdisciplinary Research in Basic Sciences, Jamia Millia Islamia, New Delhi 110025, India

2 Center of Excellence in Biotechnology Research, College of Science, King Saud University, Riyadh, Saudi Arabia

3 Protein Research Chair, Department of Biochemistry, College of Science, King Saud University, Riyadh, Saudi Arabia

4 Dr. M. A. Ansari Health Centre, Jamia Millia Islamia, New Delhi, India are available at the present. Subsequently, we have given a comprehensive overview of the spread of this infection from China to the other parts of the globe. Management of the ongoing outbreak of SARS-CoV-2 encompassing surveillance, clinical, immunological, genetic and evolutionary investigations are likely to provide the desired results. Joint efforts of global scientific community are needed at this hour in terms of enhancement of research on development of accurate diagnostics, antiviral therapeutics and finally into formation of an effective vaccine against the emerging novel coronavirus.

Keywords SARS-CoV-2 · COVID-19 · Emergence . Global transmission · Wuhan city · China

\section{Introduction}

The first announcement of a cluster of pneumonia of unknown causes was made on 31st December, 2019 in Wuhan City of China. Initially, 27 patients were reported which augmented to 41 on Jan 11, 2020, with 7 severe cases and one death [3]. Chinese authorities reported that Severe Acute Respiratory Syndrome coronavirus (SARS$\mathrm{CoV})$, Middle East Respiratory Syndrome coronavirus (MERS-CoV), Influenza, Adenovirus and other common respiratory pathogens were ruled out as these cause of pneumonia (https://www.who.int/csr/don/12-january-2020novel-coronavirus-china/en/). Later Chinese CDC identified novel coronavirus in one of the patient samples on 8th January 2020 (https://www.wsj.com/articles/china-saysperson-infected-with-new-coronavirus-has-died-11578709 453). Interestingly, the first genome (MN908947) was sequenced from an isolate of a positive patient sample and was released within next 2 days i.e. on 10th January 2020 
(http://virological.org/t/novel-2019-coronavirus-genome/319). Based on phylogenetic analysis and taxonomy, coronavirus Study Group (CSG) of the International Committee on Taxonomy of Viruses recognized the novel coronavirus as a sister to severe SARS-CoV and thus designated it as Severe Acute Respiratory Syndrome coronavirus 2 (SARS-CoV-2) [7].

The initial cases were thought to be linked to a Huanan South China Seafood wholesale market Wuhan, Hubei Province of China (https://www.chinadaily.com.cn/a/202001/01/ WS5e0c6a49a310cf3e35581e30.html). The early patients worked or visited this market. On 1st January 2020 the market was closed and was decontaminated. The early infections were probably zoonotic via seafood, bats snakes, birds or other small animals. But, the nature of initial zoonotic transmission to humans is still being investigated. Earlier zoonotic Cornaviruses like MERS-CoV and SARS-CoV were linked to camels, bats and other animals [2].

The release of the full genome of novel coronavirus within just 2 days have allowed the research organizations to become quickly occupied in development of diagnostic assays and its molecular characterization. The updates about the virus outbreak from all over the world in real time have facilitated awareness and a rapid response by the global scientific community. In context of the same we have reviewed the current outbreak with potential reflections on viral classification, clinical presentations, diagnostics, transmission dynamics, therapeutics and the present global and national expansion of SARS-CoV-2. This comprehensive review will assist in development of crucial level of awareness in the society that will further provides better management of the future viral epidemics.

\section{Classification of SARS-CoV-2}

Coronaviruses are enveloped, single stranded RNA viruses that can infect humans and animals. The SARS-CoV-2 belongs to the Order: Nidovirales and family: Coronaviridae and subfamily Orthocoronavirinae [16]. Phylogenetic analysis revealed that SARS-CoV-2 falls into the subgenus Sarbecovirus of the genus Betacoronavirus [12] which includes coronaviruses (SARS-CoV, Bat SARS-like CoV, and others) discovered in humans, bats, and other wild animals [16]. Four human coronaviruses (229E, OC43, NL63 and HKU1) are most prevalent and commonly cause moderate to mild respiratory tract illness in humans [5].The two other strains i.e. SARS-CoV and MERS-CoV are zoonotic in origin and were reported as the major cause of respiratory infections outbreak from China in 2003 and Saudi Arabia in 2012 respectively [5]. The SARS-CoV-2 or Wuhan 2019-nCov is designated as the 7 th strain of human coronaviruses. Figure 1 summarizes the brief outline about all the 7 human coronaviruses and

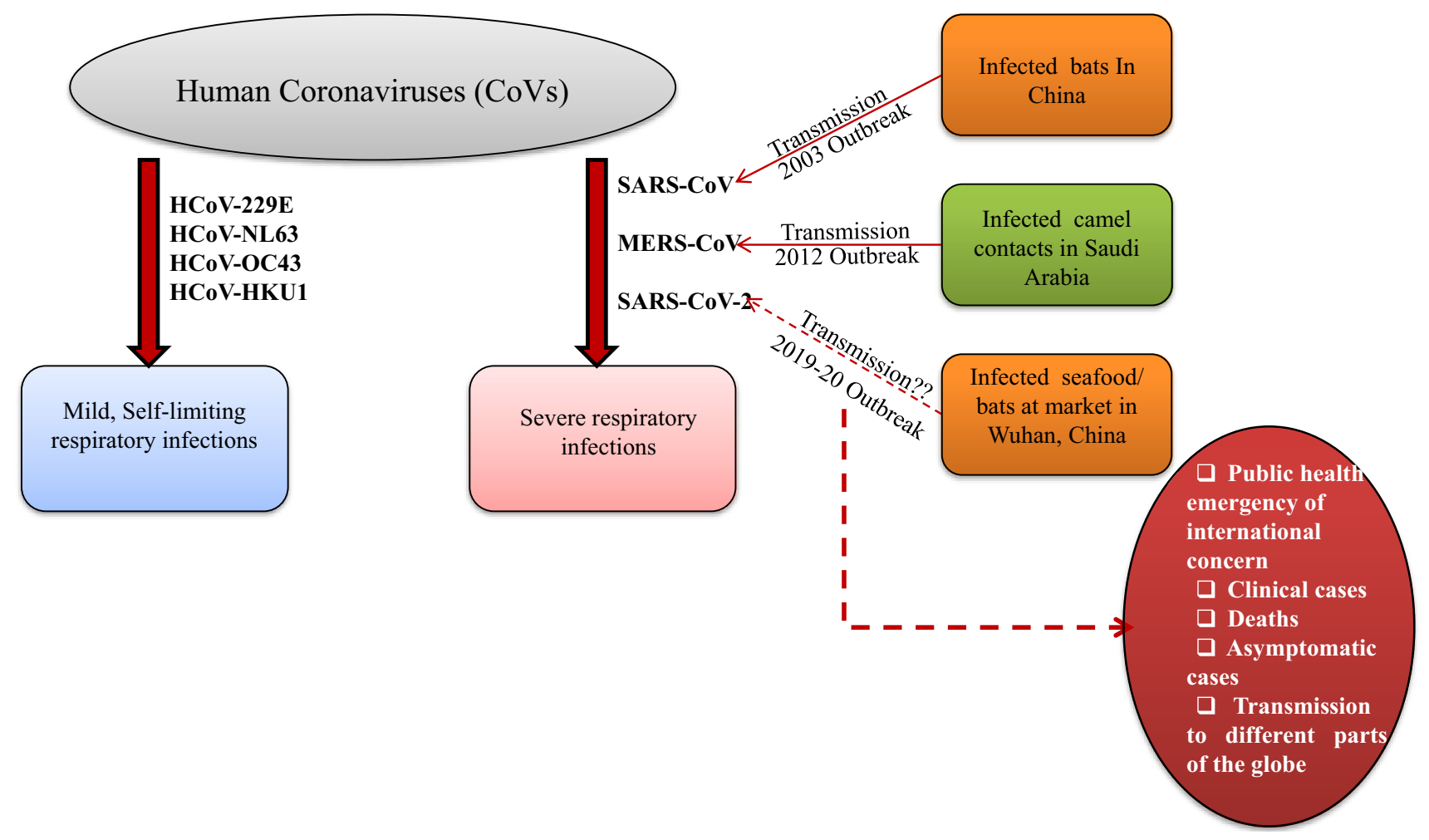

Fig. 1 A brief outline about all the human Coronaviruses and possible zoonotic emergence of three of them i.e. SARS-CoV-2, SARS-CoV and MERS-CoV. The figure also depicts some highlights of the SARS-CoV-2 outbreak 
possible zoonotic emergence of three of them i.e. SARS-CoV, MERS-CoV and SARS-CoV-2.

\section{Genome and proteins}

The genome of SARS-CoV-2 is single stranded positive sense RNA of approximately $30 \mathrm{~Kb}$ in length. The coronaviruses are comprised of four structural proteins: spike (S), envelope (E), membrane (M), and nucleocapsid (N) [6]. In SARS coronavirus, a defined receptor-binding domain (RBD) on $\mathrm{S}$ protein mediates attachment of the virus to its cellular receptor, angiotensin-converting enzyme 2 (ACE2) [11]. The most abundant and conserved $\mathrm{N}$ protein of SARS-CoV-2 is $90 \%$ identical to SARS-CoV $\mathrm{N}$ protein [8]. Moreover, the SARS-CoV-2 genome showed $80 \%$ identity with SARS-CoV and $89 \%$ similarity with Bat SARS-like CoV at nucleotide level [8]. The RBD domain of the SARS-CoV-2 S-protein supports strong interaction with human ACE2 molecules despite its sequence variation from SARS-CoV S-protein [15]. Thus, it can be postulated that SARS-CoV-2 poses health risk for human transmission via $S$ protein-ACE2 interaction pathway [15].

\section{Clinical presentation}

The confirmed cases of SARS-CoV-2 infections, have reported illnesses ranging from mild to severe illness, sometimes leading to organ failure [4]. The current estimate of the incubation period ranges from 2 to 14 days after exposure to the virus (https://www.cdc.gov/coronavirus/about/symptoms. html). Symptoms include fever, cough, and shortness of breath. Compromised lungs due to the significant infiltration in some cases may lead to multi organ failure. Some infections were severe and have led to deaths. A brief report from Wuhan Municipal Health committee has said that viral pneumonia is related to the virulence of the virus, the route of infection, age and immune status of the host (http://wjw. wuhan.gov.cn/front/web/showDetail/2019123108989).

\section{Clinical specimens}

The type of specimen that can be collected from patients under investigation for SARS-CoV-2 include: lower respiratory (bronchoalveolar lavage, tracheal aspirate and sputum), upper respiratory (nasopharyngeal swab and oropharyngeal swab, nasopharyngeal wash/aspirate or nasal aspirate) and serum specimens (https://www.cdc.gov/cor onavirus/2019-ncov/lab/guidelines-clinical-specimens.html). Mouth of the patient should be rinsed with water and then deep cough sputum should be collected. Synthetic fiber swabs with plastic shafts should be used for specimen collection. Calcium alginate swabs or swabs with wooden shafts should not be used since they may contain substances that may inactivate some viruses and inhibit PCR reaction. The collection and processing of the specimens by health care workers should be performed in sterile containers in aseptic conditions as per CDC guidelines (https:// www.cdc.gov/coronavirus/2019-nCoV/hcp/infection-con trol.html). There should be rapid collection of the samples regardless of symptoms onset and it should be guided by a trained laboratory experts. Institutional or local guidelines should be followed regarding patient or guardian's informed consent for sample collection, testing and future research. (https://www.who.int/publications-detail/labora tory-testing-for-2019-novel-coronavirus-in-suspected-humancases-20200117).

\section{Laboratory diagnosis}

The first step in diagnosis of SARS-CoV-2 is that the suspected patient should meet the criteria of case definitions outlined by WHO (https://apps.who.int/iris/bitstream/han dle/10665/330376/WHO-2019-nCoV-Surveillance-v2020. 1-eng.pdf?sequence $=5$ \&isAllowed $=y$ ). The patient with travel history to Wuhan, China and other affected countries in last few days (around 14 days) or close contact with a suspected/confirmed case of SARS-CoV-2 will be tested for the virus. The next step, include screening of the suspected patients by RT-PCR for SARS-CoV-2 (https:// www.who.int/docs/default-source/coronaviruse/peiris-pro tocol-16-1-20.pdf?sfvrsn=aflaac73_4). Due to probability of co-infection, the patient should be screened for conventional respiratory pathogens as well (https://www.who. int/publications-detail/laboratory-testing-for-2019-novelcoronavirus-in-suspected-human-cases-20200117). Further, testing based on serological assays may be useful to confirm immunological response to the virus. In addition the genomic sequencing may provide essential information about the virus like mutations, origin and its similarity with other coronaviruses. WHO can assist Member States to recognize laboratories that are able to provide support and advise them on the correct management of sequencing data obtained during an outbreak (https://www.who.int/publica tions-detail/laboratory-testing-for-2019-novel-coronavirusin-suspected-human-cases-20200117).

\section{Transmission dynamics}

Majority of the earlier cases of SARS-CoV-2 were connected to the Huanan Seafood market and it was believed that the patients could have been infected through zoonotic 
or environmental exposures [10]. Further reports of the confirmed cases and investigation of the original source of pneumonic cluster caused by SARS-CoV-2 suggests human-to-human transmission leading to epidemic expansion [10]. A probable transmission of the virus during incubation period from Germany is a disturbing factor that may lead to super spreading events $[8,14]$. Infected health care workers also contributed significantly in the transmission particularly in Wuhan city during the initial phase of the outbreak. In addition, one cannot rule out the possible transmission by the asymptomatic individuals. Clearly, there is an invisible fine line of demarcation between symptomatic and asymptomatic cases both posing a challenge to researchers. The asymptomatic cases were between 12.5 and $25 \%$ in cases of SARS outbreak [1]. Taken together, all these factors may affect the overall transmission dynamics of SARS-CoV-2 during this outbreak [14].

\section{Prevention and treatment}

No vaccine is available to prevent coronavirus disease 2019 (COVID-19) caused by SARS-CoV-2. The best means of protection is to stay away from the virus exposure. CDC has outlined preventive measures which include washing hands with soap and water for more than $20 \mathrm{~s}$. Individuals can also use an alcohol-based hand sanitizer with at least $60 \%$ alcohol. Suspected patients, health care workers and the individuals in contact with the patients should always wear face mask (N95/99) and use tissue while sneezing/coughing (https:/www.cdc.gov/coronavirus/2019-ncov/ about/prevention-treatment.html). Suspected individuals/ patients should avoid touching face, nose, eyes, tongue by hands. It is also recommended for the suspected individuals/patients that they should avoid partially cooked foods and frozen meat. These habits can be implemented on daily basis to prevent infection. Further, CDC does have specific guidance for travelers (https://wwwnc.cdc. gov/travel/notices/warning/novel-coronavirus-china). WHO has recommended few guidelines for safe home care for patients with suspected SARS-CoV-2 (https://www.who.int/ publications-detail/home-care-for-patients-with-suspectednovel-coronavirus-(ncov)infection-presenting-with-mildsymptoms-and-management-of-contacts). Moreover, the guidance documents are also developed by WHO for the appropriate management of the public health at point of entry and mass gathering (https://www.who.int/emergen cies/diseases/novel-coronavirus-2019/technical-guidance/ points-of-entry-and-mass-gatherings). No specific treatment is available against SARS-CoV-2 infection at present. Supportive care such as fluid intake, fever management, cough management, etc. is the main basis of treatment. In addition, patients with difficulty in breathing may be hospitalized and may require respiratory support in terms of oxygen supplementation. Patients of diabetes mellitus, hypertension and other chronic infections should be monitored carefully for any deterioration of vital organs. Blood pressure of the patients with hypertension should be monitored regularly and repeatedly. Urine output of the patients should also be observed to monitor the possibility of renal failure. Agranolocytosis (decrease in white blood cells due to suppression of bone marrow) is the possibility and hence these patients should be monitored for possible opportunistic infections. Future antiviral therapeutics involves research on neutralizing antibodies, passive antibodies transfer, blocking of the (ACE2) receptor to prevent binding of virion to the host cell and repurposing of available antiviral drugs [9].

\section{The ongoing outbreak}

Clinicians, researchers and health organizations are concerned about the deadly SARS-CoV-2 outbreak which has spread in different geographical locations worldwide. The daily increase in the infectious cases and death rates poses a greater challenge for the scientific community. On 30th January, the World Health Organization (WHO) declared the outbreak a "Public Health Emergency of International Concern" (http://www.euro.who.int/en/health-topics/healthemergencies/international-healthregulations/news/news/ 2020/2/2019-ncov-outbreak-is-an-emergency-of-interna tional-concern) and later a pandemic (https://www.who. int/emergencies/diseases/novel-coronavirus-2019/eventsas-they-happen). Till 18th March 2020 a total of 202,277 cases are confirmed globally with SARS-CoV-2 infection, which includes 8012 deaths and 82,813 recovered cases. Outside of China more than 1,21,000 cases including 4775 deaths, are confirmed in 166 countries and territories including the regions of Asia, Europe, Americas and Western Pacific Region (https://www.worldometers.info/cor onavirus/). China alone accounts for $40 \%(80,894)$ of this global infection of which 4\% (3237) are deaths (https:// www.worldometers.info/coronavirus/). According to an epidemic prediction, some 190,000 people could be infected in Wuhan [13]. Although the number of cases outside China is alarming but the human to human transmission poses significant public health risks. The first death outside China occurred in the Philippines followed by another at Hong kong, however, the death rates are found higher in Italy (https://www.worldometers.info/cor onavirus/) and it has become the hot-spot of maximum number of cases outside China. Also, the 3711 people on Diamond Princess ship including 1100 crew members, went into quarantine off Japan on February 5, after the 


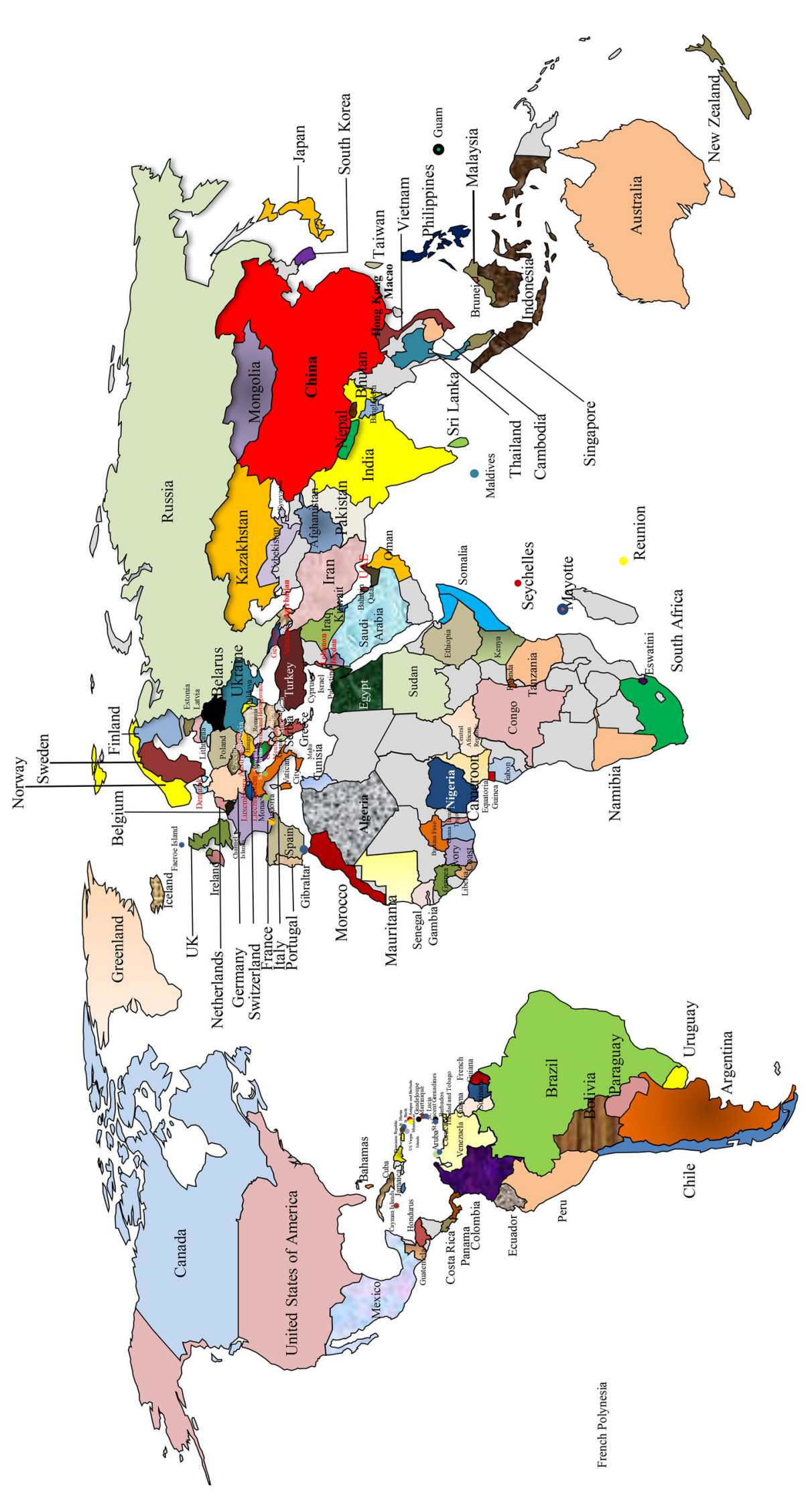

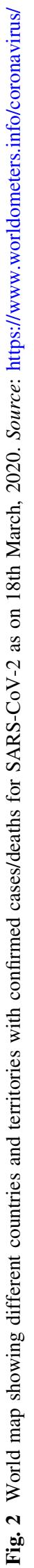


Table 1 Confirmed and death cases of SARS-CoV-2 infections worldwide as on 18th March, 2020. Source: https://www.world ometers.info/coronavirus/

\begin{tabular}{|c|c|}
\hline Country, others & Total cases/deaths \\
\hline China & $80,894 / 3,237$ \\
\hline Italy & $31,506 / 2,503$ \\
\hline Iran & $16,169 / 988$ \\
\hline Spain & $13,716 / 533$ \\
\hline Germany & $9,877 / 26$ \\
\hline S. Korea & $8,413 / 84$ \\
\hline France & $7,730 / 175$ \\
\hline USA & $6,524 / 116$ \\
\hline Switzerland & $2,742 / 27$ \\
\hline UK & $1,950 / 71$ \\
\hline Netherlands & $1,705 / 43$ \\
\hline Norway & $1,492 / 4$ \\
\hline Belgium & $1,486 / 10$ \\
\hline Austria & $1,471 / 4$ \\
\hline Sweden & $1,196 / 8$ \\
\hline Denmark & $1,044 / 4$ \\
\hline Japan & $889 / 29$ \\
\hline Malaysia & $790 / 2$ \\
\hline Diamond Princess & $712 / 7$ \\
\hline Canada & $598 / 8$ \\
\hline Australia & $565 / 6$ \\
\hline Czechia & 464 \\
\hline Portugal & $448 / 2$ \\
\hline Qatar & 442 \\
\hline Israel & 427 \\
\hline Greece & $387 / 5$ \\
\hline Brazil & $349 / 2$ \\
\hline Finland & 333 \\
\hline Ireland & $292 / 2$ \\
\hline Slovenia & $275 / 1$ \\
\hline Singapore & 266 \\
\hline Estonia & 258 \\
\hline Bahrain & $255 / 1$ \\
\hline Pakistan & $254 / 1$ \\
\hline Iceland & 247 \\
\hline Poland & $246 / 5$ \\
\hline Romania & 246 \\
\hline Indonesia & $227 / 19$ \\
\hline Thailand & $212 / 1$ \\
\hline Luxembourg & $203 / 2$ \\
\hline Philippines & $202 / 17$ \\
\hline Chile & 201 \\
\hline Egypt & $196 / 6$ \\
\hline Hong Kong & $181 / 4$ \\
\hline Saudi Arabia & 171 \\
\hline Iraq & $154 / 11$ \\
\hline India & $152 / 3$ \\
\hline
\end{tabular}

Table 1 continued

\begin{tabular}{|c|c|}
\hline Country, others & Total cases/deaths \\
\hline Kuwait & 142 \\
\hline Lebanon & $133 / 4$ \\
\hline San Marino & $119 / 11$ \\
\hline Peru & 117 \\
\hline South Africa & 116 \\
\hline Russia & 114 \\
\hline UAE & 113 \\
\hline Ecuador & $111 / 2$ \\
\hline Slovakia & 105 \\
\hline Taiwan & $100 / 1$ \\
\hline Turkey & $98 / 1$ \\
\hline Mexico & 93 \\
\hline Panama & $86 / 1$ \\
\hline Armenia & 84 \\
\hline Serbia & 83 \\
\hline Bulgaria & $81 / 2$ \\
\hline Croatia & 81 \\
\hline Argentina & $79 / 2$ \\
\hline Colombia & 75 \\
\hline Latvia & 71 \\
\hline Vietnam & 68 \\
\hline Brunei & 68 \\
\hline Algeria & $67 / 5$ \\
\hline Albania & $59 / 2$ \\
\hline Hungary & $58 / 1$ \\
\hline Faeroe Islands & 58 \\
\hline Belarus & 51 \\
\hline Costa Rica & 50 \\
\hline Uruguay & 50 \\
\hline Morocco & $49 / 2$ \\
\hline Sri Lanka & 49 \\
\hline Cyprus & 49 \\
\hline Jordan & 48 \\
\hline Palestine & 44 \\
\hline Andorra & 39 \\
\hline Georgia & 38 \\
\hline Bosnia and Herzegovina & 38 \\
\hline Malta & 38 \\
\hline Venezuela & 36 \\
\hline Cambodia & 35 \\
\hline Kazakhstan & 35 \\
\hline Azerbaijan & $34 / 1$ \\
\hline Oman & 33 \\
\hline North Macedonia & 31 \\
\hline Senegal & 31 \\
\hline Moldova & $30 / 1$ \\
\hline Tunisia & 29 \\
\hline Lithuania & 27 \\
\hline
\end{tabular}


Table 1 continued

\begin{tabular}{|c|c|}
\hline Country, others & Total cases/deaths \\
\hline Guadeloupe & 27 \\
\hline Afghanistan & 22 \\
\hline Dominican Republic & $21 / 1$ \\
\hline New Zealand & 20 \\
\hline Burkina Faso & 20 \\
\hline Martinique & $19 / 1$ \\
\hline Liechtenstein & 19 \\
\hline Macao & 15 \\
\hline Uzbekistan & 15 \\
\hline Ukraine & $14 / 2$ \\
\hline Bangladesh & $14 / 1$ \\
\hline Jamaica & 13 \\
\hline Maldives & 13 \\
\hline Bolivia & 12 \\
\hline Réunion & 12 \\
\hline Guyana & $11 / 1$ \\
\hline French Guiana & 11 \\
\hline Paraguay & 11 \\
\hline Cameroon & 10 \\
\hline Monaco & 9 \\
\hline Honduras & 9 \\
\hline Guatemala & $8 / 1$ \\
\hline Guam & 8 \\
\hline Rwanda & 8 \\
\hline Cuba & 7 \\
\hline $\mathrm{DRC}$ & 7 \\
\hline Ghana & 7 \\
\hline Kenya & 7 \\
\hline Trinidad and Tobago & 7 \\
\hline Channel Islands & 6 \\
\hline Ivory Coast & 6 \\
\hline Ethiopia & 6 \\
\hline Mongolia & 6 \\
\hline Puerto Rico & 5 \\
\hline Aruba & 4 \\
\hline Seychelles & 4 \\
\hline Nigeria & 3 \\
\hline Curaçao & 3 \\
\hline French Polynesia & 3 \\
\hline Gabon & 3 \\
\hline Gibraltar & 3 \\
\hline Kyrgyzstan & 3 \\
\hline Mayotte & 3 \\
\hline St. Barth & 3 \\
\hline Saint Martin & 3 \\
\hline Tanzania & 3 \\
\hline Sudan & $2 / 1$ \\
\hline Barbados & 2 \\
\hline
\end{tabular}

Table 1 continued

\begin{tabular}{|c|c|}
\hline Country, others & Total cases/deaths \\
\hline Liberia & 2 \\
\hline Montenegro & 2 \\
\hline Namibia & 2 \\
\hline Saint Lucia & 2 \\
\hline U.S. Virgin Islands & 2 \\
\hline Cayman Islands & $1 / 1$ \\
\hline Nepal & 1 \\
\hline Antigua and Barbuda & 1 \\
\hline Bahamas & 1 \\
\hline Benin & 1 \\
\hline Bhutan & 1 \\
\hline CAR & 1 \\
\hline Congo & 1 \\
\hline Equatorial Guinea & 1 \\
\hline Gambia & 1 \\
\hline Greenland & 1 \\
\hline Guinea & 1 \\
\hline Vatican City & 1 \\
\hline Mauritania & 1 \\
\hline Montserrat & 1 \\
\hline St. Vincent Grenadines & 1 \\
\hline Somalia & 1 \\
\hline Suriname & 1 \\
\hline Eswatini & 1 \\
\hline Togo & 1 \\
\hline Total & $202,277 / 8,012$ \\
\hline
\end{tabular}

identification of a positive test for SARS-CoV-2 from a former passenger (https://www.aljazeera.com/news/2020/ 02/passengers-leaving-diamond-princess-ship-quarantineends200219031758493.html). As of now, (18th March), 712 cases have been identified among the original 3711 people on the ship which includes 7 deaths (https://www. worldometers.info/coronavirus/).

The death rate for a virus i.e. the proportion of infected people who die is complex to estimate during an ongoing outbreak because confirmations on new cases and deaths are constantly being updated. With 8012 deaths so far out of 202,277 infections, the SARS-CoV-2 has a death rate of $4 \%$ which is significantly lower than SARS, which possess death rate of around 10\% (https://www.who.int/csr/sars/ country/Table2004_04_21/en/). The asymptomatic cases of SARS-CoV-2 may create a major problem in controlling the disease's spread and thus enhancing the virus endemicity (https://www.nature.com/articles/d41586-020-00236-9). The identified death rate for the SARS-CoV-2 may possibly decrease as mild and asymptomatic cases are identified 
(https://www.sciencemediacentre.org/expert-reaction-tonew-estimates-of-infection-rate-of-novel-coronavirus/). Many countries have evacuated their nationals from Wuhan and other cities of China and they were quarantined to monitor them for symptoms in an attempt to stop contagion (https:// www.bbc.com/news/world-asia-china-51305526). The 167 countries and territories with the confirmed cases are represented in Fig. 2. The number of confirmed and death cases of SARS-CoV-2 infection are summarized in Table 1. The virus is likely to spread to other geographical regions probably due to immunological naive population.

Further, three cases of SARS-CoV-2 in Kerala, India were confirmed on 3rd February 2020, and it was declared as a state calamity. All 3 patients had recently returned from Wuhan city of China and they got recovered from the infection as of now (https://www.indiatoday.in/india/story/ kerala-now-confirms-third-case-of-coronavirus-16427892020-02-03, https://www.worldometers.info/coronavirus/). Apart of Kerala, the suspected cases of SARS-CoV-2 have also been reported from New Delhi and NCR, Mumbai, Bengaluru, Hyderabad, Patna, etc. From 4th of March, India has made the screening tests mandatory at 21 airports, including those in Delhi, Mumbai, Kolkata, Chennai, Bengaluru, Hyderabad, and Cochin (https://www.pharma ceutical-technology.com/features/coronavirus-affected-coun tries-india-measures-impact-pharma-economy/). National Institute of Virology (NIV) Pune and Indian Council of Medical Research (ICMR) institutes are designated as laboratories meant for testing for SARS-CoV-2 in India. In addition, Ministry of Health and Family Welfare, Government of India has formulated the relevant guidelines for surveillance and clinical management of SARSCoV-2 cases (https://www.mohfw.gov.in/). Apart of thousands of infections in China, India's cases will inevitably raise further alarms over the worldwide spread of the virus as China and India currently accounts for about $37 \%$ of the global population.

\section{Concluding remarks}

Containment efforts of the pandemic will encompass timely diagnosis, quarantine of the infected individuals to prevent human to human transmission along with extensive community and hospital based surveillance. Moreover, generation of high level of awareness in the society and involvement of Government machinery will also go a long way in management of this epidemic. Elaborate investigations on transmission dynamics, clinical spectrum of disease and its correlation with genetic and immunological aspect also needs to be investigated. Phylogenetic and Bayesian analysis of the circulating strains will provide insight on the evolutionary trajectories of the virus including the origin and nucleotide substitution rates. In addition, the vaccine development efforts and identification of therapeutics including drug repurposing against SARSCoV-2 should be perused on urgent basis. Further, formulation of broad spectrum antiviral agents against human coronaviruses (SARS-CoV-2-CoV and MERS-CoV) is another aspect that can be explored in future studies. The emergence and transmission of SARS-CoV-2 to a global peril has become highly distressful. Management of this ongoing outbreak of SARS-CoV-2 is a challenge for the global community and it needs our due deliberation and immediate action.

Acknowledgements Arshi Islam is supported by Research fellowship by Indian Council of Medical Research (ICMR), Government of India.

Funding The research in our laboratory is funded by Council of Scientific and Industrial Research (CSIR), India (37(1697)17/EMRII) and Central Council for Research in Unani Medicine (CCRUM), Ministry of Ayurveda, Yoga and Naturopathy, Unani, Siddha and Homeopathy (AYUSH) (F.No. 3-63/2019-CCRUM/Tech).

Conflict of interest The authors have no conflict of interest to declare.

Ethics statement No approval of the institutional ethics committee was required for the present article.

\section{References}

1. Al-Tawfiq JA, Gautret P. Asymptomatic Middle East Respiratory Syndrome Coronavirus (MERS-CoV) infection: extent and implications for infection control: a systematic review. Travel Med Infect Disease. 2019;27:27-32. https://doi.org/10.1016/j. tmaid.2018.12.003

2. Banerjee A, Kulcsar K, Misra V, Frieman M, Mossman K. Bats and coronaviruses. Viruses. 2019. https://doi.org/10.3390/ v11010041

3. Chan JF-W, Yuan S, Kok K-H, To KK-W, Chu H, et al. A familial cluster of pneumonia associated with the 2019 novel coronavirus indicating person-to-person transmission: a study of a family cluster. Lancet. 2020;395(10223):514-23. https://doi. org/10.1016/S0140-6736(20)30154-9

4. Chen N, Zhou M, Dong X, Qu J, Gong F, Han Y, et al. Epidemiological and clinical characteristics of 99 cases of 2019 novel coronavirus pneumonia in Wuhan, China: a descriptive study. Lancet. 2020;395(10223):507-13. https://doi.org/10.1016/ S0140-6736(20)30211-7

5. Cui J, Li F, Shi ZL. Origin and evolution of pathogenic coronaviruses. Nat Rev Microbiol. 2019;17(3):181-92. https://doi.org/ 10.1038/s41579-018-0118-9

6. Fehr AR, Perlman S. Coronaviruses: an overview of their replication and pathogenesis. Methods Mol Biol. 2015;1282:1-23. https://doi.org/10.1007/978-1-4939-2438-7_1

7. Gorbalenya AE. Severe acute respiratory syndrome-related coronavirus-the species and its viruses, a statement of the Coronavirus Study Group. BioRxiv. 2020

8. Gralinski LE, Menachery VD. Return of the Coronavirus: 2019-nCoV. Viruses. 2020. https://doi.org/10.3390/v12020135 
9. Kruse RL. Therapeutic strategies in an outbreak scenario to treat the novel coronavirus originating in Wuhan, China. F1000Res. 2020;9:72. https://doi.org/10.12688/f1000research.22211.2

10. Li Q, Guan X, Wu P, Wang X, Zhou L, Tong Y, et al. Early transmission dynamics in Wuhan, China, of novel coronavirusinfected pneumonia. N Engl J Med. 2020. https://doi.org/10.1056/ NEJMoa2001316

11. Li F, Li W, Farzan M, Harrison SC. Structure of SARS coronavirus spike receptor-binding domain complexed with receptor. Science. 2005;309(5742):1864-8

12. Lu R, Zhao X, Li J, Niu P, Yang B, Wu H, et al. Genomic characterisation and epidemiology of 2019 novel coronavirus: implications for virus origins and receptor binding. Lancet. 2020;395(10224):565-74. https://doi.org/10.1016/S0140-6736 (20)30251-8

13. Read JM, Bridgen JR, Cummings DA, Ho A, Jewell CP. Novel coronavirus 2019-nCoV: early estimation of epidemiological parameters and epidemic predictions. medRxiv. 2020
14. Rothe C, Schunk M, Sothmann P, Bretzel G, Froeschl G, Wallrauch $\mathrm{C}$, et al. Transmission of 2019-nCoV infection from an asymptomatic contact in germany. $\mathrm{N}$ Engl $\mathrm{J}$ Med. 2020;382(10):970-1. https://doi.org/10.1056/NEJMc2001468

15. Xu X, Chen P, Wang J, Feng J, Zhou H, Li X, et al. Evolution of the novel coronavirus from the ongoing Wuhan outbreak and modeling of its spike protein for risk of human transmission. Sci China Life Sci. 2020;63(3):457-60. https://doi.org/10.1007/ s11427-020-1637-5

16. Zhu N, Zhang D, Wang W, Li X, Yang B, Song J, et al. A novel coronavirus from patients with pneumonia in China, 2019. N Engl J Med. 2020;382(8):727-33. https://doi.org/10.1056/ NEJMoa2001017

Publisher's Note Springer Nature remains neutral with regard to jurisdictional claims in published maps and institutional affiliations. 